\title{
MELESTARIKAN SENI TRADISI MELALUI PEMBINAAN RANDAI DI NAGARI SUNGAI LANDIA
}

\author{
Desi Susanti \\ Wenhendri
}

\author{
Prodi Seni Teater -Fakultas Seni Pertunjukan \\ Institut Seni Indonesia Padang Panjang \\ Jl. Bahder Johan. Padang Panjang. Sumatera Barat \\ desisusantiisipp@gmail.com
}

\begin{abstract}
ABSTRAK
Dewasa ini ditemui ada beberapa kesenian tradisi Minangkabau yang bisa hidup dan berkembang sesuai dengan perkembangan zaman, namun dilain pihak juga ditemui beberapa kesenian tradisi yang sudah tidak ada lagi masyarakat pendukungnya dan dikhawatirkan suatu kesenian itu akan hilang begitu saja ditelan masa. Hal yang sama juga terjadi di Nagari Sungai Landia, Kecamatan IV Koto Kabupaten Agam, Sumatera Barat. Nagari atau desa ini berada di jalur Padang Lua-Maninjau atau jalan yang menghubungkan antara Bukittinggi dan Maninjau. Pembinaan dan pelatihanan randai sebagai upaya melestarikan seni tradisi kepada generasi muda di Nagari Sungai Landia dengan tujuan untuk mendekatkan seni tradisi Minangkabau kepada generasi muda atau generasi milenial, agar kekayaan seni khas minangkabau ini tetap terawat diantara perkembangan global yang kian kuat menjauhkan generasi muda pada lingkungannya. Pembinaan dan pelatihan randai ini menggunakan metode ceramah dan praktek, dengan demikian setelah pelatihan berakhir, masyarakat atau generasi muda diharapkan mampu menguasai teknik bermain randai yang baik sehingga bisa bersaing di tingkat daerah.
\end{abstract}

Kata Kunci: Pembinaan Randai, Sungai Landai. 


\section{Jurnal Batoboh, Vol 4 , No 2, Oktober 2019 \\ Desi Susanti, Wenhendri}

\section{PENDAHULUAN}

Dewasa ini ditemui ada beberapa kesenian tradisi Minangkabau yang bisa hidup dan berkembang sesuai dengan perkembangan zaman, namun dilain pihak juga ditemui beberapa kesenian tradisi yang sudah tidak ada lagi masyarakat pendukungnya dan dikhawatirkan suatu kesenian itu akan hilang begitu saja ditelan masa

Hilangnya suatu kebudayaan masyarakat di Indonesia tidak hanya dirasakan oleh masyarakat pendukungnya, tetapi juga dirasakan oleh masyarakat Indonesia dan dunia, terutama bagi mereka yang berkecimpung dibidang kebudayaan (Ashley, 1993). Meskipun kekuatiran kita terhadap kemungkinan kesenian rakyat ini menjadi terpinggirkan dan mengalami kepunahan dalam era globalisasi, namun kita tetap memandang keberadaan music/kesenian rakyat sebagai salah satu atribut budaya yang menjadi identitas zamannya (Victor Ganap, 1995).

Melihat kondisi seperti tersebut di atas, maka pada masa globalisasi ini, pelatihan dalam upaya melestarikan kesenian tradisi perlu mendapat perhatian khusus, terutama oleh ISI Padangpanjang sebagai salah satu Perguruan Tinggi Kesenian yang mengemban tugas menggali, membina, dan mengembangkan kesenian tradisional.

Sebagaimana yang tertuang dalam Tri-Dharma Perguruan Tinggi yaitu; 1) Perguruan Tinggi berfungsi sebagai pusat pendidikan; 2) Perguruan Tinggi berfungsi sebagai pusat penelitian; 3) Perguruan Tinggi berfungsi sosial melaksanakan pengabdian pada masyarakat. Dalam hal ini pengabdian pada masyarakat merupakan dharma ketiga dari TriDharma Perguruan Tinggi dan merupakan salah satu tugas Perguruan Tinggi dalam hubungan tanggung jawabnya terhadap perkembangan dan kemajuan kelompok-kelompok 


\section{Jurnal Batoboh, Vol 4 , No 2, Oktober 2019 \\ Desi Susanti, Wenhendri}

masyarakat. Kegiatan pengabdian menjajah, yang dikenal dengan dilakukan dalam bentuk pelatihan belasting.

dalam upaya pelestarian seni tradisi.

Hal yang sama juga terjadi di Nagari Sungai Landia, Kecamatan IV Koto Kabupaten Agam, Sumatera Barat. Nagari atau desa ini berada di jalur Padang Lua-Maninjau atau jalan yang menghubungkan antara Bukittinggi dan Maninjau. Pembinaan dan pelatihanan randai sebagai upaya melestarikan seni tradisi kepada generasi muda di Nagari Sungai Landia dengan tujuan untuk mendekatkan seni tradisi Minangkabau kepada generasi muda atau generasi milenial, agar kekayaan seni khas minangkabau ini tetap terawat diantara perkembangan global yang kian kuat menjauhkan generasi muda pada lingkungannya.

Adapun naskah yang dipilih dalam pembinaan dan pelatihan randai di Nagari Sungai Landia ini berjudul Parang Kamang, yang bercerita tentang pemungutan pajak yang semena-mena dilakukan oleh Belanda ketika

\section{Masalah yang Dapat Identifikasi}

Sehubungan dengan pelatihan randai dalam upaya pelestarian seni tradisi kepada generasi muda di Nagari Sungai Landia yang menjadi sasaran dalam kegiatan ini, maka beberapa masalah yang dapat diidentifikasi sebagai berikut:

1. kurangnya minat generasi muda terhadap kesenian tradisional khususnya randai di Nagari Sungai Landia?

2. Menarik minat perhatian masyarakat khususnya generasi muda untuk mencintai kesenian tradisional (randai)?

3. Membutuhkan tenaga yang profesional dalam bidang sandiwara maupun teater tradisi (randai)

4. Perhatian pemerintah daerah yang belum menyeluruh pada kesenian disetiap desa 


\section{Jurnal Batoboh, Vol 4 , No 2, Oktober 2019 \\ Desi Susanti, Wenhendri}

Untuk itu perlu melakukan pengabdian serta pembinaan dan pelatihan pada masyarakat khususnya generasi muda Nagari Sungai Landia agar kesenian-kesenian dapat tumbuh merata pada setiap desa-desa di kecamatan IV Koto Nagari Sungai Landia, dalam hal ini dapat disimpulkan hal-hal yang perlu dibenahi pada Nagari Sungai Landia, diantaranya:

1. Mengajak generasi muda disekitar Nagari Sungai Landia untuk mengenal seni tradisi khususnya randai

2. Melatih para generasi muda untuk bermain randai

3. Memberikan pemahaman kepada masyarakat sekitar Nagari Sungai Landia agar mendukung kelompo-kelompok seni tradisi sebagai kekayaan seni pertunjukan.

4. Memotivasi pemerintah agar turut serta dalam mendukung program ini

\section{METODE PELAKSANAAN}

\section{A. Pendekataan yang ditawarkan}

Melibatkan

partisipasi

pemerintahan kabupaten Agam, Kecamatan IV Koto terutama Walinagari dan generasi muda Nagari Sungai Landia, dimulai dari perencanaan, pelaksanaan dan melanjutkan kegiatan ini sesuai kesepakatan yang dirancang secara bersama-sama. Pembinaan dan pelatihan randai dalam upaya melestarikan seni tradisi kepada generasi muda di Nagari Sungai Landia dalam pengabdian pada masyarakat ini. Membentuk kerjasama/kemitraan dengan ISI Padang Panjang sebagai perguruan tinggi seni yang terletak di kota Padang Panjang dan menjembatani pertemuan dengan pihak pemerintah dan terkait dalam program pengabdian ini.

Prosedur kerja yang akan dilaksanakan dalam Pengabdian Pada Masyarakat ini adalah:

1. Sosialisasi kegiatan 


\section{Jurnal Batoboh, Vol 4 , No 2, Oktober 2019 \\ Desi Susanti, Wenhendri}

Menjelaskan tentang randai sebagai salah satu seni tradisi di Miangkabau dan khususnya tentang cerita Randai Parang Kamang serta menumbuhkan dan membangkitkan semangat generasi muda dalam melestarikan seni tradisi ditengah era globalisasi sekarang ini. Setelah informasi sampai pada masyarakat atau generasi muda selanjutnya menjelaskan motivasi dari pengabdian pada masyarakat ini sehingga tecapai kesepakatan bersama. Membentuk kelompok yang terdiri dari 10 - 15 orang. Dan kelompok inilah yang menjadi mitra nantinya untuk kerjasama.

\section{Persiapan}

Sebelum pembinaan dan pelatihan randai dimulai, dibutuhkan persiapan yang matang agar segala proses kegiatan yang sudah direncanakan dapat terukur. Untuk itu beberapa masukan dan kebutuhan yang diharapkan masyarakat atau generasi muda didata yang kemudian disusun sebagai pedoman untuk skedul pertemuan-pertemuan kegiatan.

\section{Pelatihan}

Pelatihan dalam progam pengabdian pada masyarakat ini tentunya tidak bisa dilaksanakan setiap hari karena harus menyesuaikan dengan jadwal dan jenis pekerjaan masyarakat di Nagari Sungai Landia yang menjadi peserta kegiatan ini dan jadwal kuliah tim pengabdian masyarakat, untuk itu seluruh kegiatan ini dibuatkan jadwal pelatihan yang mengacu pada musyawarah dan mufakat. Dalam hal ini latihan hanya bisa dilakukam 1 kali seminggu selama rentang waktu 6 bulan pengabdian pada masyarakat. Adapun Metode yang digunakan dalam pelatihan ada 2 yaitu metode ceramah dan metode praktek. 


\section{Jurnal Batoboh, Vol 4 , No 2, Oktober 2019 \\ Desi Susanti, Wenhendri}

4. Penampilan

Setelah proses pertemuan latihan dianggap maksimal dibutuhkan try out ataupun penampilan hasil latihan agar apa yang disampaikan dapat terlihat manfaatnya. Penampilan ini juga bertujuan untuk memotivasi masyarakat lainnya sekitar Nagari Sungai Landia untuk melakukan hal yang sama.

\section{Seminar Internal}

Seminar Internal dilakukan sebagai ruang evaluasi dalam upaya mencari masukan-masukan dan evaluasi terhadap kerja program pengabdian pada masyarakat ini bertempat di kantor LPPMPP ISI Padangpanjang dengan tim reviewer.

\section{Pelaporan}

Setelah rangkaian kegiatan pengabdian pada masyarakat ini berakhir penulis menyusun laporan sebagai tanggung jawab penulis dalam melakukan kegiatan. Pelaporan tidak saja dalam bentuk tertulis namun juga dalam bentuk dokumentasi kegiatan.

\section{Keberlanjutan}

Program pengabdian pada masyarakat yang dijalankan ini tentunya memiliki banyak kelemahan-kelemahan sebagai sebuah awal kegiatan untuk itu penulis memerlukan keberlanjutan pada program ini.

\section{B. Materi}

Tim pelaksana dalam kegiatan ini adalah Dosen dan Mahasiswa Prodi Seni Teater, Fakultas Seni Pertunjukan yang tergabung dalam lembaga Penelitian dan Pengabdian Pada Masyarakat (LPPM) ISI Padangpanjang yang konsen pada bidang seni dan budaya dan telah melakukan beberapa penelitian, Karya Seni dan Pengabdian Pada Masyarakat. Pengabdian pada masyarakat ini tidak terlepas dari 


\section{Jurnal Batoboh, Vol 4 , No 2, Oktober 2019}

Desi Susanti, Wenhendri

peranan terkait, baik secara sesama dosen pemangku mata kuliah maupun mahasiswa yang dianggap mampu dalam bidangnya yang secara bersamasama melakukan pengabdian ketengah masyarakat.
Sesuai dengan masalah yang telah diidentifikasi maka dapat dilakukan kegiatan pengabdian sebagai berikut:

\begin{tabular}{|c|c|c|}
\hline No & MATERI KEGIATAN & REALISASI \\
\hline 1 & $\begin{array}{l}\text { Memberi penjelasan tentang } \\
\text { pentingnya pemeliharaan dan } \\
\text { penghargaan terhadap kesenian } \\
\text { tradisi sebagai salah satu budaya } \\
\text { bangsa, khususnya randai Parang } \\
\text { kamang } 1908 \text { di Nagari Sungai } \\
\text { Landia. }\end{array}$ & $\begin{array}{l}\text { Meningkatkan apresiasi para } \\
\text { peserta terhadap kesenian } \\
\text { tradisi khususnya randai Parang } \\
\text { Kamang 1908. Disamping itu } \\
\text { para peserta dapat melakukan } \\
\text { pengembangan (inovatif) dan } \\
\text { pelestarian terhadap randai } \\
\text { tersebut. }\end{array}$ \\
\hline 2 & $\begin{array}{l}\text { Memberi penjelasan tentang } \\
\text { naskah randai yang terdiri dari } 2 \\
\text { adegan. Selanjutnya juga } \\
\text { menjelaskan tentang makna dan } \\
\text { pesan yang terkandung dalam } \\
\text { naskah randai, tokoh yang } \\
\text { terlibat dalam naskah randai. } \\
\text { Disamping itu juga menjelaskan } \\
\text { tentang struktur penyajian randai } \\
\text { yang terdiri dari gurindam, }\end{array}$ & $\begin{array}{l}\text { Secara konseptual, para peserta } \\
\text { telah memiliki pengetahuan dan } \\
\text { pemahaman tentang naskah } \\
\text { randai, makna dan pesan yang } \\
\text { terkandung dalam naskah } \\
\text { randai dan struktur penyajian } \\
\text { randai. Di samping itu para } \\
\text { peserta dapat menjiwai isi pesan } \\
\text { yang terkandung dalam naskah. }\end{array}$ \\
\hline
\end{tabular}




\begin{tabular}{|c|c|c|}
\hline & $\begin{array}{l}\text { dialog, gerak galombang dan } \\
\text { tapuak galambuak yang diatur } \\
\text { oleh tukang goreh. }\end{array}$ & \\
\hline 3 & $\begin{array}{l}\text { Melatihkan teknik atau cara } \\
\text { menyanyikan gurindam randai, } \\
\text { gerak galombang dan tapuak } \\
\text { galambuak serta tukang goreh, } \\
\text { melatihkan teknik dialog yang } \\
\text { terdiri dari } 6 \text { tokoh yaitu } \\
\text { Westerneck, Dt. Rajo Pagulu, Siti } \\
\text { Asiah, Intiak Lareh, H. Jamiak, } \\
\text { Kari Mudo }\end{array}$ & $\begin{array}{l}\text { Peserta pelatihan dapat } \\
\text { memahami dan menjiwai } \\
\text { naskah dengan baik. Peserta } \\
\text { pelatihan dapat menyanyikan } \\
\text { gurindam randai dengan baik } \\
\text { dan dapat memainkan gerak } \\
\text { galombang randai serta tapuak } \\
\text { galambuak yang salah seorang } \\
\text { di antara peserta dapat } \\
\text { mengatur gerak galombang } \\
\text { (sebagai tukang goreh). }\end{array}$ \\
\hline
\end{tabular}

\section{Metode}

Sehubungan hal di atas, untuk mencapai tujuan dari kegiatan ini, kelompok pengabdian tentunya menggunakan metode ceramah, diskusi dan Tanya jawab serta praktek dalam pelatihan ini. Berikut ini dapat dilihat metode tersebut:

a. Metode ceramah dilakukan oleh seluruh para peserta pelatihan, dengan harapan agar semua peserta dapat memahami hal-hal yang berhubungan dengan randai yang akan dilatih. Dalam hal ini penyuluhan dilakukan dengan cara sebagai berikut:

- Memberi penjelasan tentang pentingnya mempelajari kesenian tradisi randai.

- Menjelaskan bahwa naskah randai Parang Kamang mengandung makna dan pesan moral, etika.

- Menjelaskan tentang unsurunsur yang terdapat dalam 


\section{Jurnal Batoboh, Vol 4 , No 2, Oktober 2019 \\ Desi Susanti, Wenhendri}

randai yaitu, cerita, dialog, gurindam, gerak galombang, musik, sastra.

b. Pelatihan/praktek

Praktek pelatihan randai dilakukan dengan menggunakan metode:

- Metode demonstrasi yaitu dengan mempraktekkan gerak-gerak galombang randai dan tapuak galambuak serta tukang goreh, gurindam, dialog untuk dapat dipahami dan ditiru oleh para peserta.

- Metode Drill; yaitu suatu metode yang diberikan kepada anggota/peserta agar materi yang sudah diajarkan diulang di rumah, sehingga anggota/peserta menguasai penampilan randai Parang Kamang yang telah diajarkan secara baik dan benar.

Pelatihan ini dilakukan dengan membagi para peserta menjadi tiga kelompok yaitu (1) Kelompok pemain gelombang randai; (2) Kelompok tokoh atau Pemeran; (3) kelompok gurindam randai dan pemusik. Setelah melakukan latihan secara terpisah, dilanjutkan dengan latihan gabungan sehingga semua peserta merasakan bahwa setiap bagian tersebut merupakan satu kesatuan yang tidak dapat dipisahkan untuk satu pertunjukan randai.

Metode-metode yang digunakan dalam kegiatan pembinaan dan pelatihan randai Parang Kamang sebagaimana tersebut di atas, diharapkan dapat membantu tercapainya keterampilan yang baik, yaitu keterampilan praktek yang disertai kesadaran dan pemahaman terhadap bagian-bagian randai yang saling terkait satu sama lainnya.

Disamping itu, metode tersebut diharapkan dapat membantu kelompok pengabdian dalam proses pelatihan sehingga para peserta pelatihan merasa termotivasi, tidak bosan untuk belajar secara serius dan tertarik terhadap materi yang diajarkan. Dengan 


\section{Jurnal Batoboh, Vol 4 , No 2, Oktober 2019}

Desi Susanti, Wenhendri

demikian para peserta bersemangat

latihan baik secara individu maupun

berkelompok walaupun tanpa kegiatan yang telah direncanakan, sebagaimana tercantum dalam jadwal kegiatan berikut ini:

bimbingan langsung atau diluar jadwal

\begin{tabular}{|c|c|c|}
\hline $\mathrm{NO}$ & HARI/TANGGAL & MATERI \\
\hline 1 & 13 Juli 2019 & $\begin{array}{c}\text { Pertemuan dengan ketua kelompok kesenian (KIEK) } \\
\text { sungai landia mufakat untuk pelatihan randai yang } \\
\text { akan dilakukan dan menjelaskan cerita randai yang } \\
\text { akan dimainkan yaitu Parang Kamang } 1908 \text { serta } \\
\text { jumlah generasi muda yang terlibat dalam pelatihan } \\
\text { ini. }\end{array}$ \\
\hline 2 & 21 Juli 2019 & $\begin{array}{l}\text { - Mengajarkan dasar-dasar gerak dan tapuak } \\
\text { galombang } \\
\text { - Mengajarkan dendang pembuka Dayang Daini }\end{array}$ \\
\hline 3 & 28 Juli 2019 & $\begin{array}{l}\text { - Mengajarkan gerak galombang berupa perintah } \\
\text { pada seluruh pemain untuk masuk ke arena. } \\
\text { - Mengajarkan Dendang simarantang }\end{array}$ \\
\hline 4 & 4 Agustus 2019 & $\begin{array}{l}\text { - Mengajarkan gerak : mengulang gerakan } \\
\text { galombang dan tapuak galamuak dari awal } \\
\text { - Mengajarkan gurindam : mengulang gurindam } \\
\text { dari awal }\end{array}$ \\
\hline 5 & 18 Agustus 2019 & Latihan Gabungan gerak dan gurindam \\
\hline 6 & 25 Agustus 2019 & $\begin{array}{l}\text { - Mengajarkan gerak lanjutan legaran II dan tapuak } \\
\text { galambuak } \\
\text { - Mengajarkan dendang lanjutan yaitu dendang } \\
\text { Andammoi }\end{array}$ \\
\hline 7 & 1 September 2019 & $\begin{array}{l}\text { - Mengulang gerak lanjutan legaran II dan tapuak } \\
\text { galambuak } \\
\text { - Mengulang dendang lanjutan yaitu dendang } \\
\text { Andam moi }\end{array}$ \\
\hline 8 & 8 September 2019 & $\begin{array}{l}\text { - Mengajarkan gerak galombang baru untuk } \\
\text { episode III dan tapuak galambuak } \\
\text { - Mengajarkan dendang Tambilang tanti batanti }\end{array}$ \\
\hline
\end{tabular}




\begin{tabular}{|c|c|c|}
\hline 9 & 15 September 2019 & $\begin{array}{l}\text { - Mengulang gerakan galombang legaran III dan } \\
\text { tapuak galambuak } \\
\text { - Mengulang dendang tambilang tanti batanti }\end{array}$ \\
\hline 10 & 22 September 2019 & $\begin{array}{l}\text { - Latihan gabungan legaran } 1 \text { sampai dengan } 2 \\
\text { - Latihan gabungan dendang dan tapuak } \\
\text { galambuak }\end{array}$ \\
\hline 11 & 29 September 2019 & $\begin{array}{l}\text { - Latihan gabungan legaran } 1,2 \text { dan } 3 \\
\text { - Latihan gabungan dendang dan tapuak } \\
\text { galambuak }\end{array}$ \\
\hline 12 & 6 Oktober 2019 & $\begin{array}{l}\text { - Latihan adegan } 1 \text { dan tapuak galambuak } \\
\text { - Latihan dendang } \\
\text { - Latihan tokoh dalam randai Adegan 1, adapun } \\
\text { tokohnya: Inyiak lareh,Westerneck, Dt. Rajo } \\
\text { Pangulu, H. Jamiak, Urang Banyak, Kari Mudo }\end{array}$ \\
\hline 13 & 13 Oktober 2019 & $\begin{array}{l}\text { - Mengulang latihan Adegan } 1 \text { lengkap dengan } \\
\text { galombang, dendang dan tokoh }\end{array}$ \\
\hline 14 & 20 Oktober 2019 & $\begin{array}{l}\text { - Latihan Adegan } 2 \text { dan } 3 \text { serta tapuak galambuak } \\
\text { - Latihan dendang } \\
\text { - Latihan tokoh dalam randai adegan } 2 \text { : Dt. Rajo } \\
\text { Pangulu, Siti Asiah } \\
\text { - Latihan tokoh dalam randai adegan } 3 \text { : } \\
\text { Westerneck, Dt. Rajo Pangulu, Siti Asiah, }\end{array}$ \\
\hline 15 & 27 Oktober 2019 & $\begin{array}{l}\text { - Latihan gabungan Adegan 1, } 2 \text { dan } 3 \\
\text { - Latihan dendang } \\
\text { - Latihan Tokoh dalam randai } \\
\end{array}$ \\
\hline 16 & 3 November 2019 & $\begin{array}{l}\text { - Latihan Akhir } \\
\text { - Pengulangan latihan adegan 1, } 2 \text { dan } 3 \text { serta } \\
\text { tapuak galambuak } \\
\text { - Latihan dendang } \\
\text { - Latihan tokoh dalam randai adegan } 1 \text { sampai } \\
\text { dengan } 3\end{array}$ \\
\hline
\end{tabular}




\section{Jurnal Batoboh, Vol 4, No1, Maret 2019 \\ Desi Susanti, Wenhendri}

Beberapa dokumentasi kegiatan Pengabdian Kepada Masyarakat di Nagari Sungai Landia:

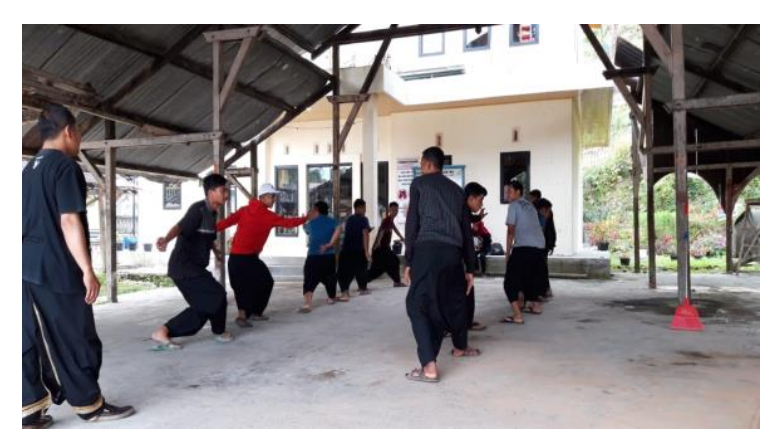

Gambar 1.

Latihan Pembuka dalam Randai

(Foto : Ventri, 2019)

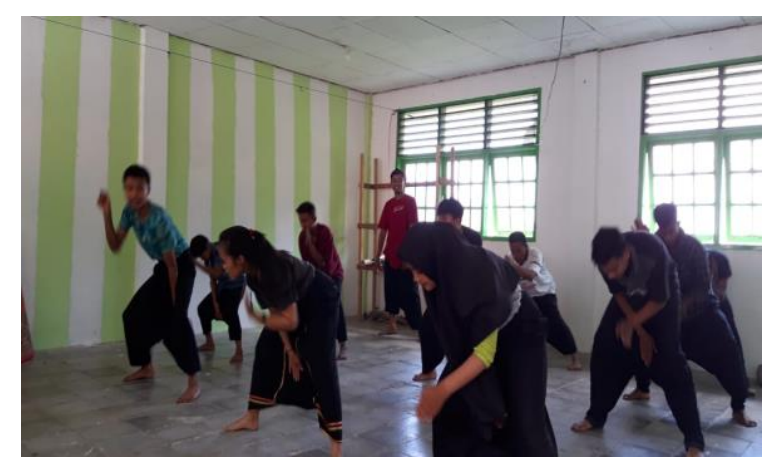

Gambar 2.

Latihan Tapuak Galambuak

(Foto : Sukra Maulana, 2019)

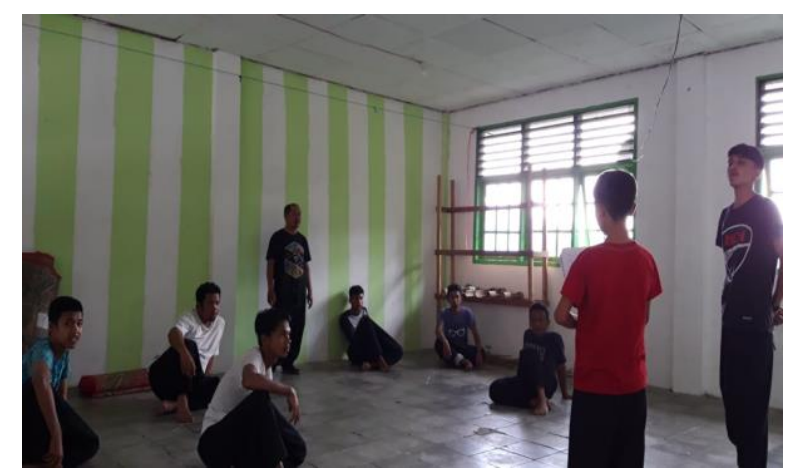

Gambar 3.

Latihan Galombang dan dialog Tokoh

(Foto : Sukra Maulana, 2019)

\section{HASIL DAN PEMBAHASAN}

Hasil dari kegiatan pembinaan dan pelatihan randai sebagai upaya melestarikan seni tradisi kepada generasi muda di Nagari Sungai Landia, adapun yang telah dilakukan pada kesempatan ini oleh kelompok pengabdian masyarakat dapat adalah mengajarkan tekhnik bermain randai, dengan naskah Parang Kamang 1908, disusun oleh S. Dt. Junjuangan dan ditulis ulang jembali oleh Wen Hendri S.Sn., M.Sn. Naskah ini terdiri dari 3 adegan yang dimainkan secara utuh yaitu galombang randai dengan tapuak galambuak, gurindam/dendang serta dialog tokoh randai. Tiga adegan tersebut telah dapat dikuasai oleh para peserta pelatihan, mereka telah dapat memainkan randai secara terstruktur yang sesuai dengan karakter naskah yang dibawakan.

Dengan telah berhasilnya para peserta pelatihan randai naskah Parang Kamang 1908, para peserta secara kreatif juga sudah dapat memberi variasi cerita dengan memasukkan suatu adegan yang berhubungan 


\section{Jurnal Batoboh, Vol 4, No1, Maret 2019 \\ Desi Susanti, Wenhendri}

dengan kebiasaan-kebiasaan yang terjadi dalam kehidupan masyarakat daerah ini, sehingga penampilan randai tersebut semakin menarik dan dapat menyentuh perasaan masyarakat setempat. Dengan demikian, berarti para peserta pelatihan sudah dapat memahami bahwa randai sesungguhnya merupakan sosio drama yang dapat mengungkapkan tentang kondisi masyarakat baik untuk pendidikan moral dalam masyarakat maupun untuk menyampaikan program-program pemerintahan.

Sehubungan dengan hal di atas, jelaslah bahwa pertunjukan randai dapat digunakan dalam berbagai kegiatan masyarakat seperti untuk memeriahkan alek nagari, pesta perkawinan dan lain-lainnya sebagainya.

\section{SIMPULAN}

Berdasarkan pengalaman selama melakukan pembinaan dan pelatihan randai sebagai upaya melestarikan seni tradisi kepada generasi muda di Nagari Sungai Landia, ada beberapa aspek yang sangat berperan dalam pemeliharaan dan pembinaan kesenian tradisional antara lain pentingnya kebersamaan masyarakat sebagai sub etnik, Minangkabau menyadari nilai keseniannnya, perhatian yang serius dari pimpinan adat dan pemerintah setempat, adanya keinginan para seniman tradisi dalam usaha regenerasi, kemasan kesenian yang cukup sederhana sehingga mudah dipelajari oleh yang berminat mempelajarinya.

Di samping itu, perhatian masyarakat terhadap kegiatan ini juga cukup tinggi, hal ini dapat dibuktikan dengan adanya tawaran masyarakat untuk menampilkan randai ini untuk memeriahkan berbagai kegiatan masyarakat seperti pengangkatan penghulu, alek kawin, turun mandi dan sebagainya. Dengan demikian jelaslah bahwa dari hasil kegiatan pengabdian masyarkat ini masyarakat nagari sungai landia dapat merasakan pentingnya keberadaan kesenian tradisi khususnya Randai untuk memeriahkan berbagai upacara adat dan kegiatan lainnya, karena ternyata randai mampu 


\section{Jurnal Batoboh, Vol 4, No1, Maret 2019 \\ Desi Susanti, Wenhendri}

menarik perhatian dan meningkatkan semangat masyarakat.

Saran

Berdasarkan kondisi yang ditemui, dapat diajukan beberapa saran agar kesenian tradisi khususnya randai di Nagari Sungai Landia dapat terbina dan terpelihara dengan baik sebagai berikut:

1. Agar pemerintah setempat menaruh perhatian yang serius terhadap pembinaan kesenian tradisi, khususnya kesenian tradisi randai.

2. Karena kondisi pakaian pemain randai tidak ada, diharapkan pada pemerintahan dapat mengadakan pakaian pemain randai, terutama celana galembong untuk bermain randai.

3. Agar ninik mamak, pemuka masyarakat dan kaum cadiak pandai melakukan usaha pembinaan kepada generasi muda, agar kesenian tradisi khususnya randai yang ada dapat berkembang dengan baik sesuai dengan etika dan moral adat dan agama.

4. Agar instansi terkait dapat memperhatikan kebutuhankebutuhan untuk pembinaan kesenian tradisi tersebut.

\section{KEPUSTAKAAN}

Ashley Turner, 1993, “Ekologi Kebudayaan Musik Masyarakat Melayu Petalangan di Riau:, dalam Seni Pertunjukan Indonesia, Jakarta. Gramedia Widiasarana Indonesia. 2003/2004, “Kisah Nan Tongga Dalam Dondang" Laporan Karya Seni, STSI Padangpanjang Ganap Victor, 1995,"Lagu Rakyat dan Kebudayaan Global". Makalah disampaikan Pada Seminar Tingkat nasional di ASKI Padangpanjang. 